\title{
Global Bromine- and Iodine-Mediated Tropospheric Ozone Loss Estimated Using the CHASER Chemical Transport Model
}

\author{
Takashi Sekiya ${ }^{1}$, Yugo Kanaya ${ }^{1}$, Kengo Sudo ${ }^{2,1}$, Fumikazu Taketani ${ }^{1}$, Yoko Iwamoto ${ }^{3}$, \\ Maki N. Aita ${ }^{1}$, Akitomo Yamamoto ${ }^{1}$, and Katsuhiro Kawamoto ${ }^{4}$ \\ ${ }^{1}$ Japan Agency for Marine-Earth Science and Technology, Yokohama, Japan \\ ${ }^{2}$ Graduate School of Environmental Studies, Nagoya University, Nagoya, Japan \\ ${ }^{3}$ Graduate School of Integrated Sciences for Life, Hiroshima University, Higashi-Hiroshima, Japan \\ ${ }^{4}$ Graduate School of Maritime Science, Kobe University, Kobe, Japan
}

\begin{abstract}
We quantified the global bromine- and iodine-mediated tropospheric ozone loss using global chemical transport model simulations. We tested three datasets of very short-lived substances (VSLS) emissions, three datasets of sea surface iodide concentrations, and an explicit representation of the effects of multiphase reactions at the air-sea boundary on dry deposition. We then determined optimal model settings based on the evaluation using the ship-borne and aircraft-campaign observations over the ocean. Our evaluation suggested that the explicit representation of multiphase reaction effects substantially reduced model biases of ozone in the lower troposphere (up to $11 \%$ ). Moreover, the impacts of using different datasets of VSLS emissions and sea-surface iodide concentrations were relatively small. The global bromine- and iodine-mediated chemical ozone losses were estimated to account for $4 \%$ and $17 \%$ of the total chemical loss, respectively, while the global iodine-mediated dry deposition loss of ozone was estimated to account for $22 \%$ of the global total dry deposition. These bromine- and iodine-mediated ozone losses decreased surface ozone concentrations over the ocean by $10 \%$ and $23 \%$, respectively. The observational constraint on model simulations made by this study supports that bromine and iodine substantially impact global tropospheric ozone through atmospheric chemical reactions and dry deposition processes.

(Citation: Sekiya, T., Y. Kanaya, K. Sudo, F. Taketani, Y. Iwamoto, M. N. Aita, A. Yamamoto, and K. Kawamoto, 2020: Global bromine- and iodine-mediated tropospheric ozone loss estimated using the CHASER chemical transport model. SOLA, 16, 220-227, doi:10.2151/sola.2020-037.)
\end{abstract}

\section{Introduction}

Understanding the processes that determine the global distribution of tropospheric ozone is essential in studies on climate change and atmospheric chemistry. Tropospheric ozone is the third most important contributor to the greenhouse gases that cause global warming (IPCC 2013). Tropospheric ozone is a major source of hydroxyl radical which affects the lifetime of methane and other greenhouse gases. Ozone is chemically produced from carbon monoxide (CO), volatile organic compounds (VOCs), and nitrogen oxides $\left(\mathrm{NO}_{\mathrm{x}}\right)$. Major sinks of tropospheric ozone are reactions with water vapor and HOx radicals, and dry deposition on the surface. The catalytic cycles with bromine and iodine also destroy ozone in the troposphere as shown in Fig. 1 (Simpson et al. 2015); however, their impacts on the loss in the global tropospheric ozone are still unclear.

Modeling studies have investigated the impacts of tropospheric bromine and iodine chemistry on tropospheric ozone distribution and budget using box models (Mahajan et al. 2009; Sommariva

Corresponding author: Takashi Sekiya, Japan Agency for Marine-Earth Science and Technology, 3173-25 Showa-machi, Kanazawa-ku, Yokohama 236-0001, Japan. E-mail: tsekiya@jamstec.go.jp. et al. 2012; Wang et al. 2015) and three-dimensional models (SaizLopez et al. 2012; Schmidt et al. 2016; Sherwen et al. 2016b). Previous studies have examined iodine chemistry processes, such as higher iodine oxides (Saiz-Lopez et al. 2014; Sherwen et al. 2016a) and nighttime chemistry (Saiz-Lopez et al. 2016). However, some global models, particularly those for studying the climate impact of tropospheric ozone, still do not consider the impacts of bromine and iodine on tropospheric composition (e.g., Young et al. 2018).

In addition, the uncertainty in the global tropospheric ozone loss mediated by bromine and iodine is influenced by the extensive uncertainty in very short-lived substance (VSLS) such as $\mathrm{CHBr}_{3}$ and $\mathrm{CH}_{2} \mathrm{Br}_{2}$ and inorganic iodine emissions (HOI and $\mathrm{I}_{2}$ ) from the ocean. The estimations of $\mathrm{CHBr}_{3}$ and $\mathrm{CH}_{2} \mathrm{Br}_{2}$ emissions by previous studies vary dramatically: by up to a factor of 10 (Bell et al. 2002; Liang et al. 2010; Ordóñez et al. 2012; Warwick et al. 2006; Ziska et al. 2013). Carpenter et al. (2013) quantified inorganic iodine emissions as a function of wind speed, atmospheric ozone, and sea surface iodide. The concentrations of sea-surface iodide in various datasets differ by a factor greater than two (Chance et al. 2014; MacDonald et al. 2014; Sherwen et al. 2019).

Bromide and iodide in seawater also play the important role of ozone sinks through multi-phase chemical reactions at the air-sea boundary (Fig. 1). The impact of bromide and iodide in seawater on ozone dry deposition velocity has been assessed (Ganzeveld et al. 2009; Luhar et al. 2017; Pound et al. 2020) and quantified over the northern hemisphere (Sarwar et al. 2015, 2016), while the global bromine- and iodine-mediated ozone dry deposition loss at the air-sea boundary was not directly quantified.

This study quantifies global tropospheric ozone loss mediated by bromine and iodine through atmospheric reactions and multiphase reactions at the air-sea boundary using model simulation with optimal settings determined by the evaluation of sensitivity simulations through the ship-borne (Kanaya et al. 2019) and aircraft-campaign observations (Wofsy et al. 2018) over the ocean where the impact of bromine and iodine on ozone is expected to be more evident. We perform the sensitivity simulations using three datasets of VSLS emissions, three parameterizations for sea-surface iodide concentrations, and two dry deposition schemes which considers multi-phase chemical reactions at the air-sea boundary or assumes the fixed deposition velocity, respectively. The remainder of this paper is structured as follows. Sections 2 and 3 describe the modeling system and observational data for validation and flux optimization, respectively. Section 4 shows the model results and Section 5 summarizes the study.

\section{CHASER chemical transport model}

\subsection{Model description}

We used the CHASER V4.0 chemical transport model (Sekiya et al. 2018; Sudo et al. 2002; Watanabe et al. 2011) at a horizontal resolution of T42 (i.e., $2.8^{\circ} \times 2.8^{\circ}$ ) with 32 vertical layers from the surface to $40 \mathrm{~km}$ altitude. CHASER V4.0 simulates spatial and temporal variations in chemical species, by calculating tracer 


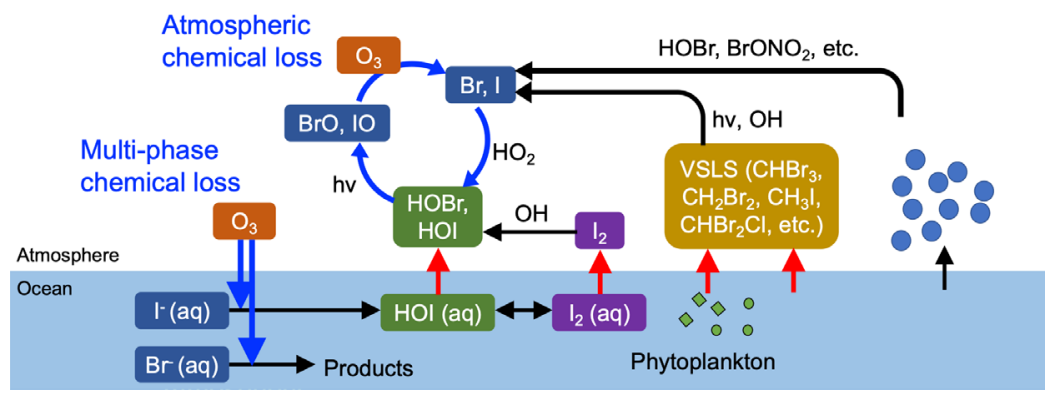

Fig. 1. Schematic diagram of bromine and iodine chemistry in the atmosphere and at the air-sea boundary. The red arrows are oceanic emissions of VSLS and inorganic iodine compounds, and the blue arrows are chemical ozone losses in the atmosphere and at the air-sea boundary. The "hv" indicates photodissociation reaction.

Table 1. Total global emissions of halocarbons and inorganic iodine compounds used in this study. MLbased data indicates machine learning-based data.

\begin{tabular}{lccc}
\hline$[\mathrm{Gg} / \mathrm{yr}]$ & $\begin{array}{c}\text { Top-down } \\
\text { (This study) }\end{array}$ & $\begin{array}{c}\text { Chl-a-based bottom-up } \\
\text { (Ordonez et al. 2012) }\end{array}$ & $\begin{array}{c}\text { Observation-based bottom-up } \\
\text { (Ziska et al. 2013) }\end{array}$ \\
\hline $\mathrm{CHBr}_{3}$ & 384 & 556 & 120 \\
$\mathrm{CH}_{2} \mathrm{Br}_{2}$ & 46 & 143 & 57 \\
$\mathrm{CH}_{2} \mathrm{BrCl}$ & - & 34 & - \\
$\mathrm{CHBr}{ }_{2} \mathrm{Cl}$ & 38 & 41 & - \\
$\mathrm{CHBrCl}$ & 44 & 54 & 290 \\
$\mathrm{CH}_{3} \mathrm{I}$ & 245 & - & - \\
$\mathrm{CH}_{2} \mathrm{ICl}$ & - & 821 & - \\
$\mathrm{CH}_{2} \mathrm{IBr}$ & - & 306 & - \\
$\mathrm{CH}_{2} \mathrm{I}_{2}$ & - & 203 & ML-based data \\
\hline \multirow{2}{*}[\mathrm{Tg}/\mathrm{yr}]{} & Parameterization 1 & Parameterization 2 & (Sherwen et al. 2019) \\
\hline $\mathrm{HOI}$ & (Chance et al. 2014) & (MacDonald et al. 2014) & 3.02 \\
$\mathrm{I}_{2}$ & 4.16 & 1.99 & 0.16 \\
\hline
\end{tabular}

transport, emissions, dry and wet deposition, and chemical processes (115 species and 309 reactions) including the ozone- $\mathrm{HO}_{\mathrm{x}}-$ $\mathrm{NO}_{\mathrm{x}}$-VOCs-CO system and halogen chemistry. Dry deposition velocity was calculated using the resistance model (Wesely 1989). The effects of the chemical reactions of atmospheric ozone with sea surface iodide, bromide, dimethyl sulfide (DMS), and dissolved organic carbon (DOC) on the dry deposition velocity were considered using the method proposed by Chang et al. (2004), instead of the fixed surface resistance $(13.3 \mathrm{~s} / \mathrm{cm})$ over the ocean in the standard model configuration. Sea-surface iodide concentrations were obtained from three parameterizations (c.f., Section 2.2), while sea surface bromide was set to $8.4 \times 10^{-4} \mathrm{~mol} / \mathrm{L}$ (Sarwar et al. 2016). The model updates made by this study are detailed in Supplement 1 .

The meteorological fields were calculated using the MIROCAGCM atmospheric general circulation model driven by the prescribed sea surface temperature (SST) and sea ice concentration obtained from the HadISST dataset (Rayner et al. 2003), and were nudged to the 6-hourly ERA-Interim reanalysis data (Dee et al. 2011) with a relaxation period of 5 days for temperature and 0.7 days for horizontal winds.

Surface emissions of ozone precursors $\left(\mathrm{NO}_{x}, \mathrm{CO}, \mathrm{NMVOCs}\right)$ were obtained from the HTAP_v2.2 inventory (Janssens-Maenhout et al. 2015), Global Fire Emission Database (GFED) version 4.1 inventory (Randerson et al. 2018), the Copernicus Atmosphere Monitoring Service (CAMS) soil emissions (Granier et al. 2019; Simpson et al. 2014), and the Model of Emission of Gases and Aerosols from Nature (MEGAN) version 2 (Guenther et al. 2006) for anthropogenic, biomass burning, soil $\mathrm{NO}_{\mathrm{x}}$, and biogenic VOC sources, respectively. Surface concentrations of long-lived halocarbons were set at the concentrations in 2000 based on the study by Meinshausen et al. (2011).

\subsection{Tropospheric bromine and iodine compounds' sources}

Global total emissions of $\mathrm{CHBr}_{3}, \mathrm{CH}_{2} \mathrm{Br}_{2}, \mathrm{CH}_{2} \mathrm{BrCl}, \mathrm{CHBrCl}_{2}$,
$\mathrm{CH}_{3} \mathrm{I}, \mathrm{CH}_{2} \mathrm{ICl}, \mathrm{CH}_{2} \mathrm{IBr}, \mathrm{CH}_{2} \mathrm{I}_{2}$, HOI, and $\mathrm{I}_{2}$ are outlined in Table 1 . We tested three datasets of VSLS emissions: (1) chlorophyll-a (Chl-a)-based bottom-up emissions which are calculated from the function of Chl-a proposed by Ordóñez et al. (2012). (2) HALOCAT-data-based bottom-up emissions developed by Ziska et al. (2013). (3) Top-down emission estimates which we optimized with NASA ATom aircraft-campaign observations (c.f., Section 3.2) using the Bayesian optimization technique in this study.

Oceanic HOI and $\mathrm{I}_{2}$ emissions were estimated using the parameterization scheme developed by Carpenter et al. (2013) as function of the near-surface atmospheric ozone mixing ratio, the sea-surface concentration of aqueous iodide, and the $10 \mathrm{~m}$ wind speed which is cut off by the predefined minimum value of $5 \mathrm{~m} \mathrm{~s}^{-1}$. Sea-surface iodide was obtained from three parameterizations: (1) the multivariable function of SST, latitude, sea-surface nitrate concentration, annual sum of ocean mixing layer depth, and sea surface salinity, which was constructed from sea surface iodide observation (Chance et al. 2014), (2) the single-variable function of SST from a laboratory experiment (MacDonald et al. 2014), and (3) 10 ensembles of regression prediction models generated from the machine learning approach (Sherwen et al. 2019) using sea surface iodide observation (Chance et al. 2019). The methods are detailed in Supplement 2.

\subsection{Simulation settings}

As summarized in Table 2, we performed seven model simulations for the period 2014-2018 to test three datasets of VSLS emissions (BASE, CHLA, ZISKA), three datasets of sea surface iodide (BASE, MACD, SHEW), the effects of multi-phase chemical reactions at the air-sea boundary on ozone dry deposition velocity (BASE, FVDO3), and the standard model configuration without tropospheric halogen chemistry (STD). We performed two sensitivity simulations without bromine and iodine chemistry to quantify their impacts on ozone concentrations (NOBRM, NOIOD). 
Table 2. Summary of sensitivity simulations.

\begin{tabular}{|c|c|c|}
\hline ID & Simulation & Description \\
\hline 1 & BASE & $\begin{array}{l}\text { Simulation with bromine and iodine chemistry and } \\
\text { air-sea boundary reactions using top-down VSLS } \\
\text { sources and parameterization } 1 \text { (Chance et al. 2014) } \\
\text { for sea-surface iodide concentrations }\end{array}$ \\
\hline 2 & CHLA & $\begin{array}{l}\text { Same as BASE, but using Chl-a-based bottom-up } \\
\text { VSLS sources. }\end{array}$ \\
\hline 3 & ZISKA & $\begin{array}{l}\text { Same as BASE, but using Observation-based bottom- } \\
\text { up VSLS sources. }\end{array}$ \\
\hline 4 & MACD & $\begin{array}{l}\text { Same as BASE, but using parameterization } 2 \text { (Mac- } \\
\text { Donald et al. 2014) for sea-surface iodide concentra- } \\
\text { tions }\end{array}$ \\
\hline 5 & SHEW & $\begin{array}{l}\text { Same as BASE, but using the machine-learning- } \\
\text { based data (Sherwen et al. 2019) for sea-surface } \\
\text { iodide concentrations }\end{array}$ \\
\hline 6 & FVDO3 & $\begin{array}{l}\text { Same as BASE, but using the fixed surface resistance } \\
\text { of ozone over the ocean }(=13.3 \mathrm{~cm} / \mathrm{s})\end{array}$ \\
\hline 7 & STD & $\begin{array}{l}\text { Simulation with standard model configuration (with- } \\
\text { out tropospheric bromine sources and iodine chem- } \\
\text { istry, and using the fixed surface resistance over the } \\
\text { ocean) }\end{array}$ \\
\hline 8 & NOIOD & Simulation without iodine chemistry and sources \\
\hline 9 & NOBRM & Simulation without bromine chemistry and sources \\
\hline
\end{tabular}

\section{Observational data}

For the comparison, the simulated concentrations were linearly interpolated to the observation location and time from the surrounding grids of a two-hourly model output. A brief description of the observations is given below.

\subsection{Ship-borne observations of R/V Mirai and Hakuho-maru}

The simulated near-surface ozone concentrations over the ocean were evaluated using the ship-borne ozone observations on R/V Mirai and Hakuho-maru of the Japan Agency for MarineEarth Science and Technology (Kanaya et al. 2019), which covers from $67^{\circ} \mathrm{S}$ to $75^{\circ} \mathrm{N}$ for 11974 hours in total for 2014-2018. The ozone concentrations were measured using UV absorption methods (Model 49C, Thermo Scientific for R/V Mirai and Model 205, 2B Technologies for R/V Hakuho-maru). The 1-min ozone data affected by the ship's exhaust and exceeding $3 \sigma$ of standard deviation in an hour were excluded before producing hourly averages.

\subsection{Aircraft-campaign observations}

Vertical profiles of VSLS $\left(\mathrm{CHBr}_{3}, \mathrm{CH}_{2} \mathrm{Br}_{2}, \mathrm{CHBr}_{2} \mathrm{Cl}, \mathrm{CHBrCl}_{2}\right.$, and $\mathrm{CH}_{3} \mathrm{I}$ ) obtained from the NASA ATom aircraft-campaign (Wofsy et al. 2018) were used for flux estimation and model evaluation. Vertical profiles of ozone were also used for the model evaluation. The VSLS concentrations were collected by the whole air sampler on NASA DC-8 aircraft and analyzed using gas chromatography (Blake et al. 2003, 2001). Ozone concentrations measured using the Unmanned Aircraft Systems (UAS) Chromatograph for Atmospheric Trace Species (UCATS) were used (Hintsa et al. 2010).

\section{Results and discussions}

\subsection{Model evaluation using ship-borne and aircraft-campaign observations}

As shown in Fig. 2, incorporating processes that are relevant to tropospheric bromine and iodine (BASE) improved the rootmean-square error (RMSE) for surface ozone against the shipborne observations by $25 \%$ to $7.5 \mathrm{ppbv}$, compared to the STD simulation, with positive bias reductions over the tropics and subtropics (Fig. 3). The RMSE for ozone against the aircraftcampaign observations in the BASE simulation was reduced by $14 \%$ to $8.4 \mathrm{ppbv}$ in the lower troposphere $(500-1000 \mathrm{hPa})$

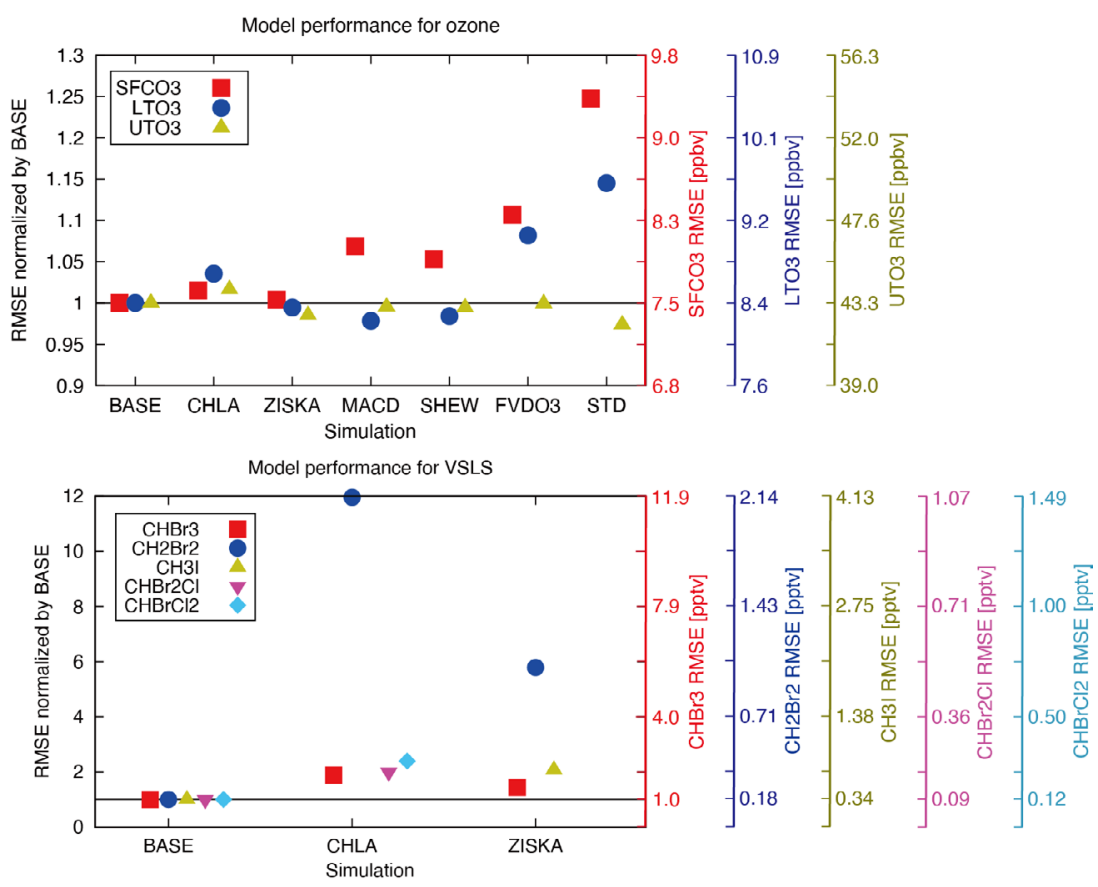

Fig. 2. Root-mean-square errors (RMSEs) for the simulated ozone (top) and VSLS concentration fields (bottom) against the ship-borne and NASA ATom aircraft-campaign observations. RMSE is normalized by the BASE simulation. For the top panel, the red square is RMSE for ozone concentrations against the ship-borne observations (SFCO3), the blue circle and yellow triangle are RMSEs for ozone concentrations against the aircraft-campaign observations in the lower (1000-500 hPa; LTO3) and upper troposphere (250-500 hPa; UTO3). For the bottom panel, the red square, the blue circle, the yellow triangle, the magenta reversed triangle, and the sky blue diamond are RMSEs for $\mathrm{CHBr}_{3}, \mathrm{CH}_{2} \mathrm{Br}_{2}, \mathrm{CH}_{3} \mathrm{I}, \mathrm{CHBr}_{2} \mathrm{Cl}$, and $\mathrm{CHBrCl}$, respectively, against the aircraftcampaign observations. 

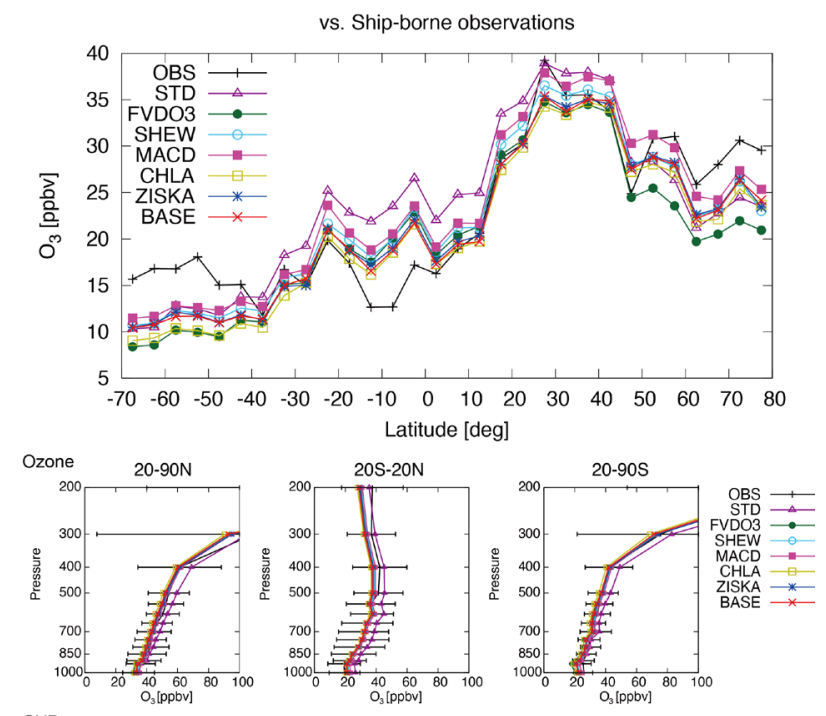

$\mathrm{CHBr}_{3}$
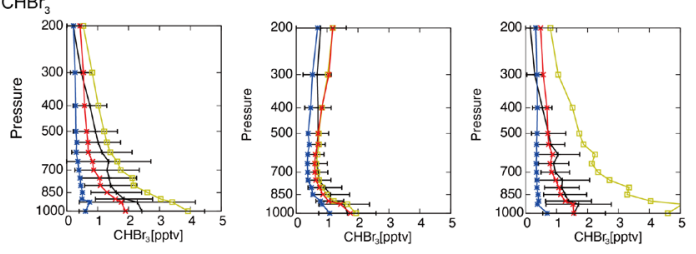

$\mathrm{CH}_{2} \mathrm{Br}_{2}$
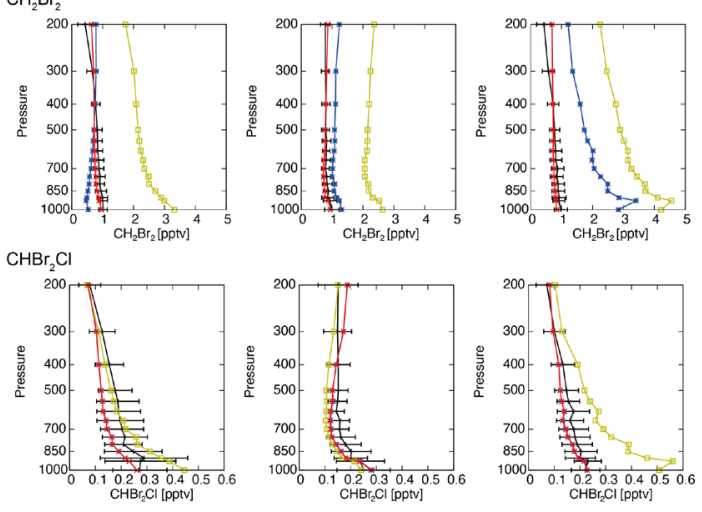

$\mathrm{CHBrCl}_{2}$
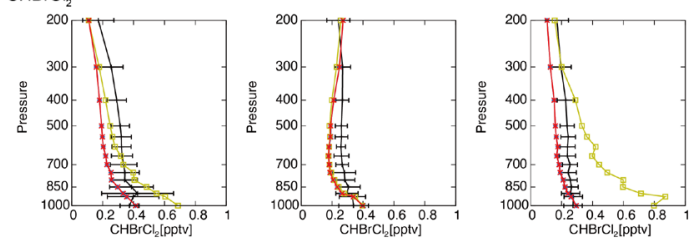

$\mathrm{CH}_{3} \mathrm{I}$
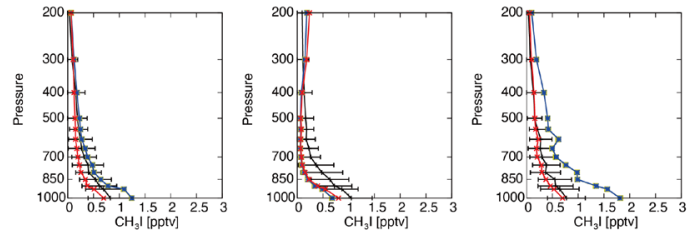

Fig. 3. Latitudinal distributions of near-surface ozone over the ocean derived from the ship-borne observations and model simulations for 20142018 (first column). The observed and simulated ozone concentrations are averaged at a $5^{\circ}$-bin grid. Vertical profiles of ozone (second column), $\mathrm{CHBr}_{3}$ (third column), $\mathrm{CH}_{2} \mathrm{Br}_{2}$ (fourth column), $\mathrm{CHBr}{ }_{2} \mathrm{Cl}$ (fifth column), $\mathrm{CHBrCl}_{2}$ (sixth column), $\mathrm{CH}_{3} \mathrm{I}$ (seventh column) derived from the NASA ATom aircraft-campaign observations and the model simulations for $2016-2018$ over $20^{\circ} \mathrm{N}-90^{\circ} \mathrm{N}$ (first row), $20^{\circ} \mathrm{S}-20^{\circ} \mathrm{N}$ (second row), and $20^{\circ} \mathrm{S}-90^{\circ} \mathrm{S}$ (third row) are also shown. The black line is the observations, and the red, blue, yellow, magenta, skyblue, green, and purple lines indicate the BASE, ZISKA, CHLA, MACD, SHEW, FVDO3, and STD simulations, respectively. The unit is ppbv for ozone and pptv for other species. compared to the STD simulation, whereas RMSE was slightly increased by $3 \%$ to $43.3 \mathrm{ppbv}$ in the upper troposphere (250$500 \mathrm{hPa}$ ). The increase in RMSE could partly be attributed to overestimation in the simulated convective mass flux to the upper troposphere (above $500 \mathrm{hPa}$ ) by a factor of two against the MERRA-2 reanalysis (Gelaro et al. 2017).

The use of the Chl-a-based bottom-up emissions (CHLA) and the HALOCAT-data-based bottom-up emissions (ZISKA) had little effect on the model performance for ozone $(<4 \%)$. Tropospheric $\mathrm{BrO}$ concentrations (averaged in $0-8 \mathrm{~km}$ altitude) during daytime (10-15LT) over tropical western Pacific Ocean in the BASE, CHLA, and ZISKA simulations $(0.59,0.65$, and 0.47 pptv, respectively) ranged within the observed values of 0.17-1.64 pptv from the NERC Co-ordinated Airborne Studies in the Tropics (CAST) aircraft campaign (Le Breton et al. 2017), suggesting consistency of VSLS emissions tested in this study with the $\mathrm{BrO}$ observations.

Meanwhile, the RMSEs for $\mathrm{CHBr}_{3}, \mathrm{CH}_{2} \mathrm{Br}_{2}, \mathrm{CHBr}_{2} \mathrm{Cl}$, and $\mathrm{CHBrCl}_{2}$ concentrations against the aircraft-campaign observations were reduced by $47 \%, 92 \%, 50 \%$, and $58 \%$, respectively, in the BASE simulation compared to the CHLA simulation. Compared to the ZISKA simulation, the RMSEs for $\mathrm{CHBr}_{3}, \mathrm{CH}_{2} \mathrm{Br}_{2}$, and $\mathrm{CH}_{3} \mathrm{I}$ against the aircraft-campaign observations were reduced by $30 \%, 83 \%$, and $52 \%$, respectively. Model biases of these species in the BASE simulation were largely reduced in the lower troposphere especially over $20^{\circ} \mathrm{S}-90^{\circ} \mathrm{S}$, compared to the CHLA and ZISKA simulations (Fig. 3), especially in austral winter (Supplement 3). These results suggested that improvements in VSLS emissions had relatively small impacts on tropospheric ozone.

Consistencies with the ship-borne observations in the BASE simulation were improved by $5-7 \%$ compared to the MACD and SHEW simulations, while the RSMEs for ozone against the aircraft-campaign observations were within $2.2 \%$ in the BASE, MACD, SHEW simulations. The positive biases of surface ozone in the BASE simulation were smaller than those in the MACD simulation and were comparable to the SHEW simulation (Fig. 3). The day-time IO concentrations in the boundary layer over $45^{\circ} \mathrm{S}-$ $45^{\circ} \mathrm{N}$ in the BASE, MACD, SHEW simulations $(0.65,0.42$, and $0.52 \mathrm{pptv}$, respectively) were within the observed ranges of $0.4-$ 1 pptv (Prados-Roman et al. 2015a). However, Sherwen et al. (2019) reported that the machine-learning-based sea-surface iodide (used in the SHEW simulation) shows better agreements with the observations than the others. Smaller model biases in the BASE simulation may be influenced by model biases irrelevant to iodide or unaccounted iodine sources (e.g., Watanabe et al. 2019).

The RMSEs for ozone against the ship-borne observations and the aircraft-campaign observation in the lower troposphere were reduced by $11 \%$ and $7 \%$, respectively, by the explicit model representation of ozone dry deposition (BASE) compared to the use of the fixed surface resistance (FVDO3). The RMSE reduction was attributed to negative bias reductions by $20-50 \%$ over the high latitudes of both hemisphere (Fig. 3), resulting from the ozone increases over the Arctic and Southern Ocean, as consistently reported in Pound et al. (2020).

These evaluation results suggest that the BASE simulation is the most consistent with the ship-borne and aircraft-campaign observations among the sensitivity simulations performed in this study. Therefore, we use the BASE simulation to estimate impacts of bromine and iodine chemistry on the global tropospheric ozone budget and concentrations.

\subsection{Global tropospheric ozone loss mediated by bromine and iodine}

Using the BASE simulation, the global bromine-mediated chemical ozone loss was estimated to be $166 \mathrm{Tg} / \mathrm{yr}(122-223 \mathrm{Tg} / \mathrm{yr}$ using different VSLS fluxes), corresponding to $4 \%$ of the total chemical loss (Table 3). The global iodine-mediated chemical loss was estimated to be $693 \mathrm{Tg} / \mathrm{yr}(522-706 \mathrm{Tg} / \mathrm{yr}$ using different parameterizations), which contributed to $17 \%$ of the total chemical loss. Multi-phase reactions with sea-surface iodide contributed to $22 \%$ of the global total dry deposition ozone loss, whereas the impact of bromine was negligible. The total chemical production and loss in the BASE simulation were slightly larger than the STD simulation, whereas the total dry deposition flux was $15 \%$ 
Table 3. Global tropospheric ozone budget obtained from the BASE and STD simulations. The ranges obtained from the sensitivity simulations, except the STD, NOIOD, and NOBRM simulations, are indicated in brackets. STE indicates stratosphere-troposphere exchange.

\begin{tabular}{lccr}
\hline \multicolumn{1}{c}{$[\mathrm{Tg} / \mathrm{yr}]$} & BASE & Range & STD \\
\hline Chemical Production & 4527 & $(4445-4543)$ & 4355 \\
\hline Chemical Loss & 4018 & $(3997-4032)$ & 3759 \\
$\mathrm{O}(1 \mathrm{D})+\mathrm{H}_{2} \mathrm{O}$ & 1607 & $(1584-1677)$ & 1831 \\
$\mathrm{O}_{3}+\mathrm{HO}_{2}$ & 1024 & $(998-1083)$ & 1264 \\
$\mathrm{O}_{3}+\mathrm{OH}$ & 415 & $(408-430)$ & 463 \\
Bromine-mediated loss & 166 & $(122-223)$ & 78 \\
Iodine-mediated loss & 693 & $(522-706)$ & - \\
\hline Dry deposition & 878 & $(826-915)$ & 1040 \\
Bromine-mediated loss & 0.07 & $(0.07-0.12)$ & - \\
Iodine-mediated loss & 193 & $(116-195)$ & - \\
\hline STE & 368 & $(352-388)$ & 444 \\
\hline
\end{tabular}

smaller. Considering chemical and dry deposition processes, total iodine-mediated ozone loss was estimated to be $886 \mathrm{Tg} / \mathrm{yr}$.

Compared to previous estimates of $178-405 \mathrm{Tg} / \mathrm{yr}$ (Sherwen et al. 2016a, 2016b), our estimate of the global bromine-mediated ozone loss was comparable to the lower end. Conversely, our estimated global iodine-mediated ozone loss was close to the higher end of previous estimate ranges of 280-748 Tg/yr (Prados-Roman et al. 2015b; Sherwen et al. 2016a, 2016b). These differences could be attributed to differences in VSLS and inorganic iodine sources, and model processes such as using the constant uptake coefficient for heterogeneous reactions on sea-salt particles. The global iodine-mediated ozone dry deposition loss was not evaluated in the previous studies, while our estimate of total dry deposition over the ocean $(277 \mathrm{Tg} / \mathrm{yr})$ was smaller than the multi-model ensemble of $335 \mathrm{Tg} / \mathrm{yr}$ reported in Hardacre et al. (2015) and was larger than the state-of-the-art model estimate of $122 \mathrm{Tg} / \mathrm{yr}$ by Pound et al. (2020).

\subsection{Impact of bromine and iodine on tropospheric ozone distribu- tion}

The impacts of bromine- and iodine-mediated ozone losses on ozone concentrations were quantified (Fig. 4) using the NOBRM and NOIOD simulations. Global mean near-surface ozone concentration over the ocean decreased by $10 \%$ due to bromine-mediated ozone loss, while zonal-mean ozone concentrations typically decreased by $10-15 \%$ in the free troposphere. Iodine-mediated ozone losses decreased global mean near-surface ozone over the ocean by $23 \%$, and ozone in the free troposphere by $15 \%$.

\section{Summary and conclusion}

This study quantified global tropospheric ozone loss mediated by bromine and iodine using model simulation. We tested three datasets of VSLS emissions, three datasets of sea surface iodide concentrations, and an explicit representation of the effects of multi-phase chemical reactions on ozone dry deposition. We then determined the optimal model setting through the evaluation of
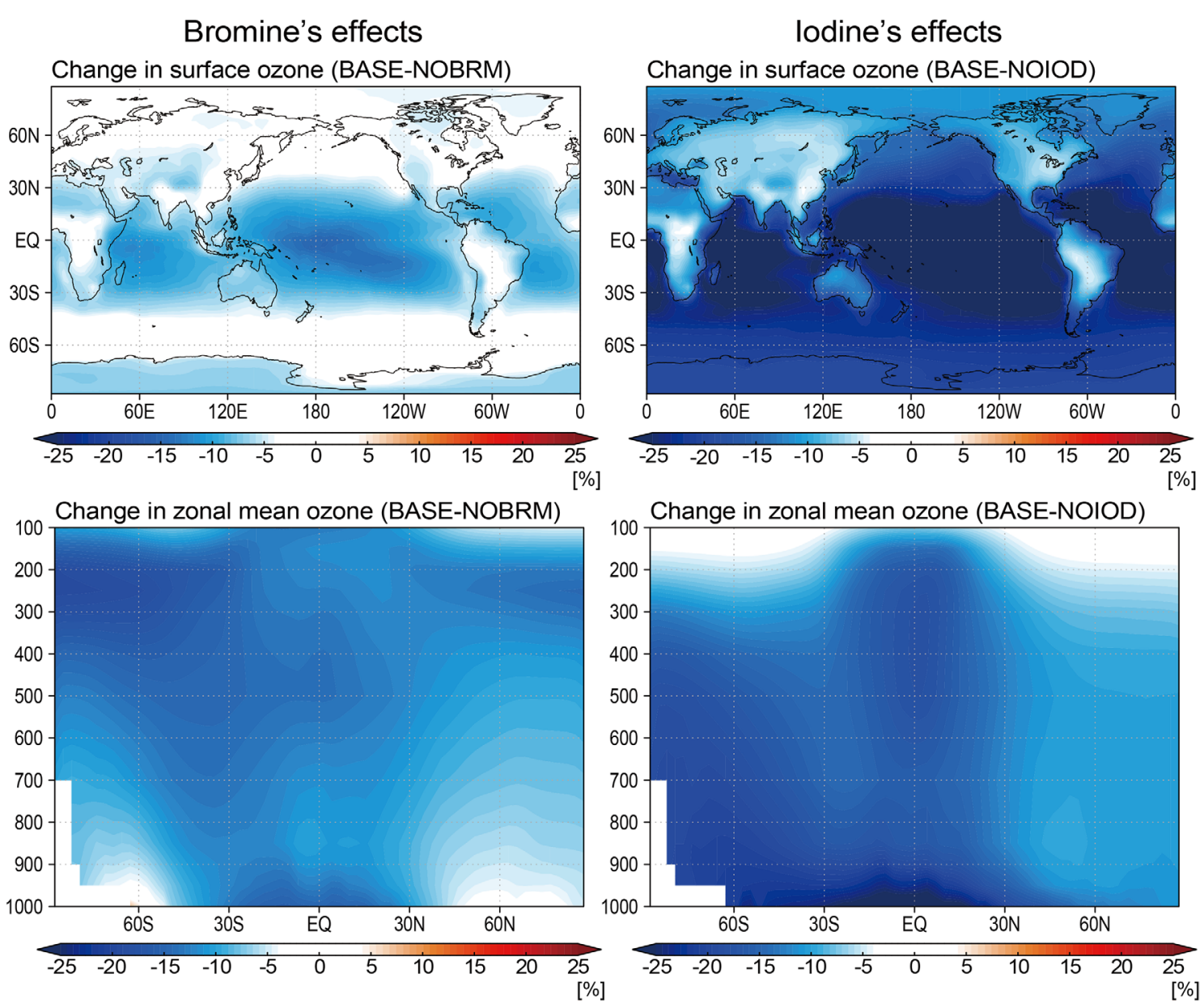

Fig. 4. Impacts of bromine (left) and iodine (right) chemistry on annual mean ozone concentration fields (\%) through atmospheric chemical reactions and multi-phase reactions at air-sea boundary. The top represents near-surface ozone concentrations, and the bottom represents the zonal mean ozone concentrations. 
sensitivity simulations using the ship-borne and aircraft-campaign observations. Our evaluation suggests that the explicit representation of multi-phase reaction effects substantially reduced RMSEs against the observations (by up to $11 \%$ ), and the impact of using different datasets of VSLS emissions and sea-surface iodide concentrations were relatively small.

The global tropospheric ozone losses mediated by bromine and iodine were estimated to account for $4 \%$ and $17 \%$ of the total chemical ozone loss, respectively, based on the simulation with the optimized setting. The global tropospheric ozone loss associated with ozone-iodine reactions at the sea-surface corresponded to $22 \%$ of the total ozone dry deposition loss. The global mean near-surface ozone concentration over the ocean was reduced by $10 \%$ and $23 \%$ owing to the bromine- and iodine-mediated ozone losses, respectively.

The observational constraint on model simulations made by this study supports that bromine and iodine substantially impact global tropospheric ozone through atmospheric chemical reactions and dry deposition processes, whereas the estimates is not fully constrained. To obtain more reliable estimates, understanding of the processes (e.g., $\mathrm{I}_{\mathrm{x}} \mathrm{O}_{\mathrm{y}}$ photolysis, Lewis et al. 2020), which are more relevant to halogen chemistry and emission, would be needed. Further observational constraints on bromine and iodine compounds such as $\mathrm{BrO}, \mathrm{IO}$, and $\mathrm{HOI}$ in the marine boundary layers would also contribute to better understanding of the impacts of bromine and iodine on global tropospheric ozone.

\section{Acknowledgements}

This work was supported by the JSPS Grant-in-Aid for Scientific Research (18H03369) and the Research Grant from Asahi Group Foundation. We acknowledge the use of the ship-borne observations from R/V Mirai and Hakuho-maru, and the NASA ATom aircraft-campaign data from the NASA Ames Earth Science Project Office (https://espo.nasa.gov/atom). The Earth Simulator was used for simulations with the support of the Japan Agency for Marine-Earth Science and Technology.

Edited by: D. Goto

\section{Supplements}

Supplement 1: Details of model updates. fluxes.

Supplement 2: Detailed methods for oceanic VSLS and iodine

Supplement 3: Additional validation results.

\section{References}

Bell, N., L. Hsu, D. J. Jacob, M. G. Schultz, D. R. Blake, J. H. Butler, D. B. King, Lobert J. M., and E. Maier-Reimer, 2002: Methyl iodide: Atmospheric budget and use as a tracer of marine convection in global models. J. Geophys. Res., 107, ACH-8.

Blake, N. J., D. R. Blake, I. J. Simpson, J. P. Lopez, N. A. C. Johnston, A. L. Swanson, A. S. Katzenstein, S. Meinardi, B. C. Sive, J. J. Colman, E. Atlas, F. Flocke, S. A. Vay, M. A. Avery, and F. S. Rowland, 2001: Large-scale latitudinal and vertical distributions of NMHCs and selected halocarbons in the troposphere over the Pacific Ocean during the MarchApril 1999 Pacific Exploratory Mission (PEM-Tropics B). $J$. Geophys. Res., 106, 32627-32644.

Blake, N. J., D. R. Blake, I. J. Simpson, S. Meinardi, A. L. Swanson, J. P. Lopez, A. S. Katzenstein, B. Barletta, T. Shirai, E. Atlas, G. Sachse, M. Avery, S. Vay, H. E. Fuelberg, C. M. Kiley, K. Kita, and F. S. Rowland, 2003: NMHCs and halocarbons in Asian continental outflow during the Transport and Chemical Evolution over the Pacific (TRACE-P) Field Campaign: Comparison with PEM-West B. J. Geophys.
Res., 108, doi:10.1029/2002JD003367.

Carpenter, L. J., S. M. MacDonald, M. D. Shaw, R. Kumar, R. W. Saunders, R. Parthipan, J. Wilson, and J. M. C. Plane, 2013: Atmospheric iodine levels influenced by sea surface emissions of inorganic iodine. Nat. Geosci., 6, 108-111.

Chance, R., A. R. Baker, L. Carpenter, and T. D. Jickells, 2014: The distribution of iodide at the sea surface. Environ. Sci. Process. Impacts, 16, 1841-1859.

Chance, R. J., L. Tinel, T. Sherwen, A. R. Baker, T. Bell, J. Brindle, A. Maria Lucia, P. Croot, H. Ducklow, H. Peng, F. Hopkins, B. Hoogakker, C. Hughes, T. D. Jickells, D. Loades, D. A. R. Macaya, A. S. Mahajan, G. Malin, D. Phillips, I. Roberts, R. Roy, A. Sarkar, A. K. Sinha, X. Song, H. Winkelbauer, K. Wuttig, M. Yang, Z. Peng, and L. J. Carpenter, 2019: Global sea-surface iodide observations, 1967-2018. Sci. Data, 6, 1-8.

Chang, W., B. G. Heikes, and M. Lee, 2004: Ozone deposition to the sea surface: chemical enhancement and wind speed dependence. Atmos. Environ., 38, 1053-1059.

Dee, D. P., S. M. Uppala, A. J. Simmons, P. Berrisford, P. Poli, S. Kobayashi, U. Andrae, M. A. Balmaseda, J. Bidlot, N. Bormann, C. Delsol, R. Dragani, M. Fuentes, A. J. Geer, L. Haimberger, S. B. Healy, H. Hersbach, E. V. Hólm, L. Isaksen, P. Kållberg, M. Köhler, M. Matricardi, A. P. McNally, B. M. Monge-Sanz, J.-J. Morcrette, B.-K. Park, C. Peubey, P. de Rosnay, C. Tavolato, J.-N. Thépaut, and F. Vitart, 2011: The ERA-Interim reanalysis: Configuration and performance of the data assimilation system. Quart. J. Roy. Meteor. Soc., 137, 553-597.

Ganzeveld, L., D. Helmig, C. W. Fairall, J. Hare, and A. Pozzer, 2009: Atmosphere-ocean ozone exchange: A global modeling study of biogeochemical, atmospheric, and waterside turbulence dependencies. Global Biogeochem. Cy., 23, GB4021.

Gelaro, R., W. McCarty, M. J. Suárez, R. Todling, A. Molod, L. Takacs, C. A. Randles, A. Darmenov, M. G. Bosilovich, R. Reichle, K. Wargan, L. Coy, R. Cullather, C. Draper, S. Akella, V. Buchard, A. Conaty, A. M. da Silva, W. Gu, G.-K. Kim, R. Koster, R. Lucchesi, D. Merkova, J. E. Nielsen, G. Partyka, S. Pawson, W. Putman, M. Rienecker, S. D. Schubert, M. Sienkiewicz, and B. Zhao, 2017: The Modern-Era Retrospective analysis for Research and Applications, version 2 (MERRA-2). J. Climate, 30, 5419-5454.

Granier, C., S. Darras, H. D. van der Gon, D. Jana, N. Elguindi, G. Bo, G. Michael, G. Marc, J.-P. Jalkanen, J. Kuenen, C. Liousse, B. Quack, D. Simpson, and K. Sindelarova, 2019: The Copernicus Atmosphere Monitoring Service global and regional emissions (April 2019 version). Copernicus Atmosphere Monitoring Service (CAMS) Report, doi:10.24380/ d0bn-kx16.

Guenther, A., T. Karl, P. Harley, C. Wiedinmyer, P. I. Palmer, and C. Geron, 2006: Estimates of global terrestrial isoprene emissions using MEGAN (Model of Emissions of Gases and Aerosols from Nature). Atmos. Chem. Phys., 6, 3181-3210.

Hardacre, C., O. Wild, and L. Emberson, 2015: An evaluation of ozone dry deposition in global scale chemistry climate models. Atmos. Chem. Phys., 15, 6419-6436.

Hintsa, E. J., F. L. Moore, G. S. Dutton, B. D. Hall, and J. W. Elkins, 2010: First Results from UCATS during the GloPac 2010 Mission. The AGU Fall Meeting Abstracts, A51B0093.

IPCC, 2013: Contribution of working group I to the fifth assessment report of the intergovern-mental panel on climate change. Climate Change 2013: The Physical Science Basis, T. F. Stocker, D. Qin, G.-K. Plattner, M. Tignor, S. K. Allen, J. Boschung, A. Nauels, Y. Xia, V. Bex, and P. M. Midgley, Eds., Cambridge University Press, Cambridge, United Kingdom and New York, NY, USA, 1535 pp.

Janssens-Maenhout, G., M. Crippa, D. Guizzardi, F. Dentener, M. Muntean, G. Pouliot, T. Keating, Q. Zhang, J. Kurokawa, R. Wankmüller, H. Denier van der Gon, J. J. P. Kuenen, Z. Klimont, G. Frost, S. Darras, B. Koffi, and M. Li, 2015: 
HTAP v2.2: a mosaic of regional and global emission grid maps for 2008 and 2010 to study hemispheric transport of air pollution. Atmos. Chem. Phys., 15, 11411-11432.

Kanaya, Y., K. Miyazaki, F. Taketani, T. Miyakawa, H. Takashima, Y. Komazaki, X. Pan, S. Kato, K. Sudo, T. Sekiya, J. Inoue, K. Sato, and K. Oshima, 2019: Ozone and carbon monoxide observations over open oceans on R/V Mirai from $67^{\circ} \mathrm{S}$ to $75^{\circ} \mathrm{N}$ during 2012 to 2017 : Testing global chemical reanalysis in terms of Arctic processes, low ozone levels at low latitudes, and pollution transport. Atmos. Chem. Phys., 19, 7233-7254.

Le Breton, M., T. J. Bannan, D. E. Shallcross, M. A. Khan, M. J. Evans, J. Lee, R. Lidster, S. Andrews, L. J. Carpenter, J. Schmidt, D. Jacob, N. R. P. Harris, S. Bauguitte, M. Gallagher, A. Bacak, K. E. Leather, and C. J. Percival, 2017: Enhanced ozone loss by active inorganic bromine chemistry in the tropical troposphere. Atmos. Environ., 155, 21-28.

Lewis, T. R., J. C. Gómez Martin, M. A. Blitz, C. A. Cuevas, J. M. C. Plane, and A. Saiz-Lopez, 2020: Determination of the absorption cross-sections of higher order iodine oxides at $355 \mathrm{~nm}$ and $532 \mathrm{~nm}$. Atmos. Chem. Phys., 20, 10865-10887.

Liang, Q., R. S. Stolarski, S. R. Kawa, J. E. Nielsen, A. R. Douglass, J. M. Rodriguez, D. R. Blake, E. L. Atlas, and L. E. Ott, 2010: Finding the missing stratospheric Bry: A global modeling study of $\mathrm{CHBr}_{3}$ and $\mathrm{CH}_{2} \mathrm{Br}_{2}$. Atmos. Chem. Phys., 10, 2269-2286.

Luhar, A. K., I. E. Galbally, M. T. Woodhouse, and M. Thatcher, 2017: An improved parameterisation of ozone dry deposition to the ocean and its impact in a global climate-chemistry model. Atmos. Chem. Phys., 17, 3749-3767.

MacDonald, S. M., J. C. Gómez Martín, R. Chance, S. Warriner, A. Saiz-Lopez, L. J. Carpenter, and J. M. C. Plane, 2014: A laboratory characterisation of inorganic iodine emissions from the sea surface: dependence on oceanic variables and parameterisation for global modelling. Atmos. Chem. Phys., 14, 5841-5852.

Mahajan, A. S., H. Oetjen, A. Saiz-Lopez, J. D. Lee, G. B. McFiggans, and J. M. C. Plane, 2009: Reactive iodine species in a semi-polluted environment. Geophys. Res. Lett., 36, L16803.

Meinshausen, M., S. J. Smith, K. Calvin, J. S. Daniel, M. L. T. Kainuma, J.-F. Lamarque, K. Matsumoto, S. A. Montzka, S. C. B. Raper, K. Riahi, A. Thomson, G. J. M. Velders, and D. P. P. van Vuuren, 2011: The RCP greenhouse gas concentrations and their extensions from 1765 to 2300 . Climate Change, 109, 213.

Ordóñez, C., J.-F. Lamarque, S. Tilmes, D. E. Kinnison, E. L. Atlas, D. R. Blake, G. Sousa Santos, G. Brasseur, and A. Saiz-Lopez, 2012: Bromine and iodine chemistry in a global chemistry-climate model: description and evaluation of very short-lived oceanic sources. Atmos. Chem. Phys., 12, $1423-1447$.

Prados-Roman, C., C. A. Cuevas, T. Hay, R. P. Fernandez, A. S. Mahajan, S.-J. Royer, M. Galí, R. Simó, J. Dachs, K. Großmann, D. E. Kinnison, J.-F. Lamarque, and A. SaizLopez, 2015a: Iodine oxide in the global marine boundary layer. Atmos. Chem. Phys., 15, 583-593.

Prados-Roman, C., C. A. Cuevas, R. P. D. Fernandez, E. Kinnison, J.-F. Lamarque, and A. Saiz-Lopez, 2015b: A negative feedback between anthropogenic ozone pollution and enhanced ocean emissions of iodine. Atmos. Chem. Phys., 15, 22152224.

Pound, R. J., T. Sherwen, D. Helmig, L. J. Carpenter, and M. J. Evans, 2020: Influences of oceanic ozone deposition on tropospheric photochemistry. Atmos. Chem. Phys., 20, 42274239.

Randerson, J. T., G. R. van der Werf, L. Giglio, G. J. Collatz, and P. S. Kasibhatla, 2018: Global Fire Emissions Database, Version 4.1 (GFEDv4). ORNL DAAC, Oak Ridge, Tennessee, USA. doi:10.3334/ORNLDAAC/1293.

Rayner, N. A., D. E. Parker, E. B. Horton, C. K. Folland, L.V. Alexander, D. P. Rowell, E. C. Kent, and A. Kaplan, 2003:
Global analyses of sea surface temperature, sea ice, and night marine air temperature since the late nineteenth century. J. Geophys. Res., 108, 4407.

Saiz-Lopez, A., R. P. Fernandez, C. Ordóñez, D. E. Kinnison, J. C. Gomez Martin, J. F. Lamarque, and S. Tilmes, 2014: Iodine chemistry in the troposphere and its effect on ozone. Atmos. Chem. Phys., 14, 13119-13143.

Saiz-Lopez, A., J.-F. Lamarque, D. E. Kinnison, S. Tilmes, C. Ordóñez, J. J. Orlando, A. J. Conley, J. M. Plane, A. S. Mahajan, G. Sousa Santos, and co-authors, 2012: Estimating the climate significance of halogen-driven ozone loss in the tropical marine troposphere. Atmos. Chem. Phys., 12, 3939-3949.

Saiz-Lopez, A., J. Plane, C. A. Cuevas, A. S. Mahajan, J.-F. Lamarque, and D. E. Kinnison, 2016: Nighttime atmospheric chemistry of iodine. Atmos. Chem. Phys., 16, 15593-15604.

Sarwar, G., B. Gantt, D. Schwede, and K. Foley, 2015: Impact of enhanced ozone deposition and halogen chemistry on tropospheric ozone over the Northern Hemisphere. Environ. Sci. Technol., 49, 9203-9211.

Sarwar, G., D. Kang, K. Foley, D. Schwede, B. Gantt, and R. Mathur, 2016: Examining ozone deposition over seawater. Atmos. Environ., 141, 255-262.

Schmidt, J. A., D. J. Jacob, H. M. Horowitz, L. Hu, T. Sherwen, M. J. Evans, Q. Liang, R. M. Suleiman, D. E. Oram, M. Le Breton, C. J. Percival, S. Wang, B. Dix, and R. Volkamer, 2016: Modeling the observed tropospheric BrO background: Importance of multiphase chemistry and implications for ozone, OH, and mercury. J. Geophys. Res., 121, 1181911835 .

Sekiya, T., K. Miyazaki, K. Ogochi, K. Sudo, and M. Takigawa, 2018: Global high-resolution simulations of tropospheric nitrogen dioxide using CHASER V4.0. Geosci. Model Dev., 11, 959-988.

Sherwen, T., R. J. Chance, L. Tinel, D. Ellis, M. J. Evans, and L. J. Carpenter, 2019: A machine learning based global seasurface iodide distribution. Earth Syst. Sci. Data, 11, 12391262.

Sherwen, T., M. J. Evans, L. J. Carpenter, S. J. Andrews, R. T. Lidster, B. Dix, T. K. Koenig, R. Sinreich, I. Ortega, R. Volkamer, A. Saiz-Lopez, C. Prados-Roman, A. S. Mahajan, and C. Ordóñez, 2016a: Iodine's impact on tropospheric oxidants: A global model study in GEOS-Chem. Atmos. Chem. Phys., 16, 1161-1186.

Sherwen, T., J. A. Schmidt, M. J. Evans, L. J. Carpenter, K. Großmann, S. D. Eastham, D. J. Jacob, B. Dix, T. K. Koenig, R. Sinreich, I. Ortega, R. Volkamer, A. Saiz-Lopez, C. Prados-Roman, A. S. Mahajan, and C. Ordóñez, 2016b: Global impacts of tropospheric halogens $(\mathrm{Cl}, \mathrm{Br}, \mathrm{I})$ on oxidants and composition in GEOS-Chem. Atmos. Chem. Phys., 16, 12239-12271.

Simpson, D., C. Andersson, J. H. Christensen, M. Engardt, C. Geels, A. Nyiri, M. Posch, J. Soares, M. Sofiev, P. Wind, and J. Langner, 2014: Impacts of climate and emission changes on nitrogen deposition in Europe: A multi-model study. Atmos. Chem. Phys., 14, 6995-7017.

Simpson, W. R., S. S. Brown, A. Saiz-Lopez, J. A. Thornton, and R. von Glasow, 2015: Tropospheric halogen chemistry: Sources, cycling, and impacts. Chem. Rev., 115, 4035-4062.

Sommariva, R., W. J. Bloss, and R. von Glasow, 2012: Uncertainties in gas-phase atmospheric iodine chemistry. Atmos. Environ., 57, 219-232.

Sudo, K., M. Takahashi, J. Kurokawa, and H. Akimoto, H., 2002: CHASER: A global chemical model of the troposphere 1. Model description. J. Geophys. Res., 107, ACH7-1ACH7-20.

Wang, S., J. A. Schmidt, S. Baidar, S. Coburn, B. Dix, T. K. Koenig, E. Apel, D. Bowdalo, T. L. Campos, E. Eloranta, M. J. Evans, J. P. DiGangi, M. A. Zondlo, R.-S. Gao, J. A. Haggerty, S. R. Hall, R. S. Hornbrook, D. Jacob, B. Morley, B. Pierce, M. Reeves, P. Romashkin, A. Ter Schure, and R. Volkamer, 2015: Active and widespread halogen chemistry 
in the tropical and subtropical free troposphere. Proc. Natl. Acad. Sci., 112, 9281-9286.

Warwick, N. J., J. A. Pyle, G. D. Carver, X. Yang, N. H. Savage, F. M. O'Connor, and R. A. Cox, 2006: Global modeling of biogenic bromocarbons. J. Geophys. Res., 111, D24305.

Watanabe, S., T. Hajima, K. Sudo, T. Nagashima, T. Takemura, H. Okajima, T. Nozawa, H. Kawase, M. Abe, T. Yokohata, T. Ise, H. Sato, E. Kato, K. Takata, S. Emori, and M. Kawamiya, 2011: MIROC-ESM 2010: Model description and basic results of CMIP5-20c3m experiments. Geosci. Model Dev., 4, 845-872.

Watanabe, K., S. Matsuda, C. A. Cuevas, A. Saiz-Lopez, A. Yabushita, and Y. Nakano, 2019: Experimental determination of the photooxidation of aqueous I- as a source of atmospheric $\mathrm{I}_{2}$. ACS Earth Space Chem., 3, 4, 669-679.

Wesely, M. L., 1989: Parameterization of surface resistances to gaseous dry deposition in regional-scale numerical models. Atmos. Environ., 23, 1293-1304.

Wofsy, S. C., S. Afshar, H. M. Allen, E. C. Apel, E. C. Asher, B. Barletta, J. Bent, H. Bian, B. C. Biggs, D. R. Blake, N. Blake, C. A. Brock, W. H. Brune, J. W. Budney, T. P. Bui, A. Butler, P. Campuzano-Jost, C. S. Chang, M. Chin, R. Commane, G. Correa, J. D. Crounse, P. D. Cullis, B. C. Daube, D. A. Day, J. M. Dean-Day, J. E. Dibb, J. P. DiGangi, G. S. Diskin, M. Dollner, J. W. Elkins, F. Erdesz, A. M. Fiore, C. M. Flynn, K. D. Froyd, D. W. Gesler, S. R. Hall, T. F. Hanisco, R. A. Hannun, A. J. Hills, E. J. Hintsa, A. Hoffman, R. S. Hornbrook, L. G. Huey, S. Hughes, J. L. Jimenez, B. J. Johnson, J. M. Katich, R. F. Keeling, M. J. Kim, A. Kupc, L. R. Lait, J.-F. Lamarque, J. Liu, K. McKain, R. J. Mclaughlin, S. Meinardi, D. O. Miller, S. A. Montzka, F. L. Moore, E. J. Morgan, D. M. Murphy, L. T. Murray, B. A. Nault, J. A. Neuman, P. A. Newman, J. M. Nicely, X. Pan, W. Paplawsky, J. Peischl, M. J. Prather, D. J.
Price, E. Ray, J. M. Reeves, M. Richardson, A. W. Rollins, K. H. Rosenlof, T. B. Ryerson, E. Scheuer, G. P. Schill, J. C. Schroder, J. P. Schwarz, J. M. St. Clair, S. D. Steenrod, B. B. Stephens, S. A. Strode, C. Sweeney, D. Tanner, A. P. Teng, A. B. Thames, C. R. Thompson, K. Ullmann, P. R. Veres, N. Vieznor, N. L. Wagner, A. Watt, R. Weber, B. Weinzierl, P. O. Wennberg, C. J. Williamson, J. C. Wilson, G. M. Wolfe, C. T. Woods, and L. H. Zeng, 2018: ATom: Merged atmospheric chemistry, trace gases, and aerosols. ORNL DAAC, Oak Ridge, Tennessee, USA, doi:10.3334/ORNLDAAC/1581.

Young, P. J., V. Naik, A. M. Fiore, A. Gaudel, J. Guo, M. Y. Lin, J. Neu, D. Parrish, H. E. Reider, J. L. Schnell, S. Tilmes, O. Wild, L. Zhang, J. Brandt, A. Delcloo, R. M. Doherty, C. Geels, M. Hegglin, L. Hu, U. Im, R. Kumar, A. Luhar, L. Murray, D. Plummer, J. Rodriguez, A. Saiz-Lopez, M. G. Schultz, M. Woodhouse, G. Zeng, and J. Ziemke, 2018: Tropospheric Ozone Assessment Report: Assessment of global-scale model performance for global and regional ozone distributions, variability, and trends. Elem. Sci. Anth., 6, 10 .

Ziska, F., B. Quack, K. Abrahamsson, S. D. Archer, F. Atlas, T. Bell, J. H. Butler, L. J. Carpenter, C. E. Jones, N. R. P. Harris, H. Hepach, K. G. Heumann, C. Hughes, J. Kuss, K. Krüger, P. Liss, R. M. Moore, A. Orlikowska, S. Raimund, C. E. Reeves, W. Reifenhäuser, A. D. Robinson, C. Schall, T. Tanhua, S. Tegtmeier, S. Turner, L. Wang, D. Wallace, J. Williams, H. Yamamoto, S. Yvon-Lewis, and Y. Yokouchi, 2013: Global sea-to-air flux climatology for bromoform, dibromomethane and methyl iodide. Atmos. Chem. Phys., 13, 8915-8934.

Manuscript received 18 May 2020, accepted 25 September 2020 SOLA: https://www.jstage.jst.go.jp/browse/solal 